Dossiê: Lutero e a Reforma: 500 anos - Artigo Original @-

DOI - 10.5752/P.2175-5841.2016v14n44p1173

\title{
Nem Sola Scriptura, Nem Solus Spiritus: a revelação na dimensão do humano
}

\author{
Neither Sola Scriptura, Nor Solus Spiritus: The revelation in the human \\ dimension
}

\section{Abdruschin Schaeffer Rocha*}

\begin{abstract}
Resumo
O presente artigo se propõe discutir a revelação na dimensão do humano. Nesse sentido, parte do pressuposto de que tanto no protestantismo histórico quanto no pentecostalismo tal dimensão, e as contingências que daí derivam, não foram devidamente consideradas, na medida em que ambas as tradições recorrem a uma suposta "garantia da pureza" da revelação. No protestantismo, tal garantia fora buscada nas Escrituras, na medida em que ao evocar a autoridade das Escrituras, os reformadores acreditavam poder garantir a integridade da revelação, dentro de um suposto "ambiente higienizado"; no pentecostalismo, essa suposta segurança fora afiançada pelo Espírito, afinal, alimenta-se da forte expectativa de um encontro pessoal com Deus, que em sua imediaticidade supostamente garantiria a pureza da revelação. Assumindo as limitações e subjetividade humanas inerentes ao processo de recepção da revelação, propõe-se, portanto, uma revelação que se dê nos limites da história; uma revelação que se dê nos limites da linguagem; e uma revelação que se dê nos limites da vulnerabilidade humana.
\end{abstract}

Palavras-chave: Sola Scriptura; Solus Spiritus; Protestantismo Histórico; Pentecostalismo; Dimensão humana.

\begin{abstract}
This present article aims to discuss the revelation in the human dimension. In this sense, it presupposes that both in the historical Protestantism as in the Pentecostalism, such dimension and its derived contingencies were not properly considered, as both traditions make use of an alleged "guarantee of purity" from the revelation. In the historical protestantism such guarantee was sought in the Scriptures, in a way that by evoking the authority of the Scripture the Reformers believed they could ensure the integrity of the revelation, within a supposed "sanitized environment". In the pentecostalism, this supposed security was guaranteed by the Spirit, after all, it's fueled by strong expectation of a personal meeting with God, and that such immediacy would ensure the purity of the revelation. By assuming human limitations and subjectivity that are inherent in receiving a revelation, we propose, therefore, $a$ revelation that is constituted within the limits of history; a revelation that is constituted within the limits of language; a revelation that is constituted within the limits of human vulnerability.
\end{abstract}

Keywords: Sola Scriptura; Solus Spiritus; Historical Protestantism; Pentecostalism; Human dimension.

Artigo submetido em 24 de fevereiro de 2016 e aprovado em 25 de novembro de 2016.

* Doutor em Teologia pela PUC-Rio e mestre em Teologia pela EST, professor do curso de Bacharelado em Teologia e do Programa de Pós-Graduação (Mestrado Profissional) em Ciências das Religiões da Faculdade Unida de Vitória (Vitória/ES). País de Origem: Brasil. E-mail: abdrus@gmail.com.

Horizonte, Belo Horizonte, v. 14, n. 44, p. 1173-1192, out./dez. 2016 - ISSN 2175-5841 


\section{Introdução}

A história tem nos mostrado com razoável clareza que a relação entre revelação e humanidade tem sido compreendida, em geral, com estranheza e desconforto dada a força de sua contradição. As realidades que se delineiam a partir dessas expressões parecem se mostrar tão francamente contraditórias que supostamente seria um absurdo tentar uma conciliação. Talvez isso se deva, em grande medida, à condição extraordinária que tem marcado o sagrado ao longo do tempo, condição essa que o coloca como um ente qualitativamente distinto de seus pares. Tal compreensão do sagrado, grosso modo, desconsidera sua ligação indissolúvel com o profano. A pergunta, então, parece inevitável: como falar do sagrado de maneira a honrar e preservar sua sacralidade, sua distinção, seu caráter extraordinário? Essa face extraordinária do sagrado, qual luzeiro que dissipa as trevas, também tem sido interpretada como incompatível com a "escuridão" das contradições da linguagem e das ambiguidades humanas, daí a dificuldade de se estabelecer uma relação amistosa entre revelação e humanidade de tal maneira a sustentar novas e criativas formulações sobre o tema.

Na tentativa de sugerir caminhos alternativos para a construção de uma teologia da revelação, que inclua o humano e suas contingências, o presente artigo justifica sua proposta a partir do modo como duas importantes tradições do protestantismo compreenderam o tema da revelação. Referimo-nos ao protestantismo histórico e ao pentecostalismo. O protestantismo histórico acentuou demasiadamente o papel das Escrituras, na forma de um sola scriptura. Diante do movediço terreno sobre o qual a tradição parecia se sustentar, os primeiros reformadores acreditaram poder garantir a integridade da revelação, dentro de um suposto ambiente livre das interferências humanas, apelando à autoridade das Escrituras. Por outro lado, numa tentativa de denunciar a "racionalização" e "domesticação" do sagrado, operada pelo protestantismo histórico, o pentecostalismo surge como movimento popular e laico, numa atitude de recuperação do elemento místico da fé. O centro da revelação, então, passa a ser 
a experiência "direta” com o divino por meio do Espírito Santo. Também aqui há uma expectativa de se garantir a pureza da revelação, já que o tipo de relação que aí se sustenta supostamente estaria livre das mediações humanas. Trata-se de uma compreensão da revelação que se propõe na base de um solus spiritus.

Pressupondo, pois, a insuficiência tanto das Escrituras quanto da experiência por meio do Espírito, propõe-se uma revelação que também se compreenda a partir de limites mais amplos, quais sejam: uma revelação que se dê nos limites da história; uma revelação que se dê nos limites da linguagem; e uma revelação que se dê nos limites da vulnerabilidade humana.

\section{1 "Sola Scriptura"?}

Uma das principais características que têm marcado o protestantismo, desde suas origens, é a significativa ênfase dada às Escrituras, cuja importância pode ser compreendida, em certo sentido, a partir de uma crítica voraz ao peso excessivo dado à tradição, postura que desde então traduz em grande medida a distinção entre católicos e protestantes. A tradição que está sendo discutida inclui tanto as questões relativas ao "princípio hierárquico" - que revelavam uma confusão entre o "político" e o "religioso" - quanto aquelas de cunho teológico, que inspiraram as críticas de Lutero e seus contemporâneos e que geraram as três principais doutrinas do protestantismo: a justificação pela fé, o sacerdócio universal e a infalibilidade apenas das Escrituras. Mas, deve-se observar que, ao defender o sola scriptura, Lutero não rejeita a tradição, apenas afirma que quaisquer elementos que a compõem, tais como os credos, as afirmações dos pais da igreja, ou mesmo as decisões conciliares, devem ser julgados pela norma normans ("norma determinadora”) das Escrituras e a ela submetidos (WACHHOLZ, 2010, p. 110).

A Reforma é primordialmente uma resposta religiosa à imensa angústia coletiva que reinava na Europa, já que diferentes pessoas, de diferentes níveis econômicos e culturais optaram por ela. Há um sentimento generalizado de 
culpabilidade capaz de abalar e desorientar os espíritos, tanto quanto de fomentar ainda mais a prática pecaminosa, e que será respondido na forma de uma "vingança divina" instrumentalizada pela Igreja. Numa atmosfera de pessimismo e inquietude, o rigor da justiça humana justifica-se numa suposta justiça divina que encoraja a busca e punição daqueles que aparentemente se entregaram a Satanás. A doutrina da justificação pela fé, precedida por esse sentimento de culpabilidade em nível pessoal, torna avassaladora a preocupação pela salvação individual, algo significativamente diferente da compreensão coletiva de salvação, característica de uma vivência mais comunitária da Igreja, predominante até o século XIII (DELUMEAU, 1989, p. 60-64).

A paulatina ascensão do individualismo, ${ }^{1}$ além de uma depreciação do sacerdócio manifesta na falta de pastoreio, favorece a consolidação do sacerdócio universal. Esse individualismo inevitavelmente contribui para afirmação do espírito laico na medida em que parece dilatar as fronteiras da autonomia humana, além do fato de que a confusão das hierarquias e dos valores torna difícil a distinção nítida entre o padre e o leigo. Ou seja, os defeitos da igreja, somados ao clima de insegurança e à paulatina autonomia dos leigos, dão luz a uma espécie de "anarquismo" cristão no final da Idade Média (DELUMEAU, 1989, p. 68-70). Nesse sentido, os tempos de acentuada desconfiança em relação ao clero tornam urgente o estabelecimento de uma nova autoridade infalível - não sujeita aos homens e sua inconstância moral - que se constitua numa base segura que emane "diretamente" do próprio Deus. Para os reformadores, é de suma importância que se inicie a reflexão "com o tema da revelação de Deus em Jesus Cristo" (WACHHOLZ, 2010, p. 107), mas é subordinado a essa compreensão que se estabelece o princípio de autoridade da Bíblia. Nesse sentido, na perspectiva do protestantismo nascente, a presença divina se faz sentir, primordialmente, pela

\footnotetext{
${ }^{1}$ Embora se possa dizer que o "individualismo" moderno - que se consolida a partir do século XVI e tem sua maior expressão no Iluminismo do século XVIII - remonta ao próprio cristianismo, sobretudo, no que respeita aos conceitos de pessoa, liberdade e tempo linear (ver, por exemplo, as seguintes obras: GALIMBERTI, 2003, p. 127, 131, 146; ELIADE, 1992, p. 105, 111, 139; RUBIO, A. G. Novos rumos da antropologia teológica cristã. In: RUBIO, 2007, p. 263-265.), seu pano-de-fundo histórico mais próximo é o Renascimento e o humanismo que dali deriva. Sem dúvida, esses movimentos que consolidam o projeto moderno trazem luz à aproximação metodológica de apropriação das Escrituras como fonte principal de revelação.
} 
Palavra. As Escrituras, então, garantem a integridade da revelação e tornam-se o último recurso, o "fundamento" supostamente destinado a sobreviver à mais impiedosa descrença. A doutrina da infalibilidade ${ }^{2}$ apenas das Escrituras, nesse sentido, responde de modo eficaz a tais necessidades (DELUMEAU, 1989, p. 76).

Não se pode ignorar, também, as consequências mais agressivas desse acentuado peso dado a uma revelação que restringe às Escrituras sua dimensão fontal. É o caso, por exemplo, do iconoclasmo que se seguiu à Reforma e que na opinião de muitos historiadores constituiu-se numa das maiores catástrofes na história da humanidade. Embora o aniquilamento das imagens dos templos tenha se iniciado na primavera de 1522, em Wittenberg, essa paixão brutal varreu boa parte da Europa, repetindo-se, sobretudo, nos lugares onde a Reforma se instalou. Em pouco tempo destruiu-se obras de arte que foram reunidas nas igrejas ao longo de várias gerações, e aqueles afrescos que não puderam ser destruídos foram cobertos por tinta (DREHER, 1996, p. 54). Não se pode ser simplista quanto aos motivos que levaram ao iconoclasmo, mas, certamente, uma de suas principais motivações encontra-se na nova compreensão sobre a centralidade das Escrituras no contexto da teologia da cruz e da justificação. Por exemplo: o mentor intelectual do iconoclasmo em Wittenberg, Andreas Bodenstein, de Karlstadt, foi o primeiro a exprimir suas reflexões sobre cruz, justificação e imagens. Escreveu e publicou, no inverno de 1521-1522, um livreto com o título Da eliminação das imagens (Von Abtun der Bilder) que, embora pequeno, teve graves consequências na medida em que fomentou a destruição de muitas obras de arte. Para Karlstadt, tolerar imagens nas igrejas seria o equivalente a afrontar o primeiro mandamento, na medida em que equivaleria a colocar sobre os altares as próprias invenções do demônio. A posição de Karlstadt rompe com uma convicção que havia se estabelecido desde Gregório Magno, segundo a qual “as imagens eram os livros dos leigos”. É claro que os simpatizantes de Karlstadt, que aquiescem à sua conclamação, não o fazem

\footnotetext{
2 Embora o conceito de infalibilidade evocado no contexto da Reforma nos permita compreendê-lo mais em termos "doutrinários", ou seja, em termos de conteúdos garantidores da revelação divina, não se pode ignorar que tal conceito se amplia e se adensa a partir do século XIX, como resultado de uma reação fundamentalista à teologia liberal, discussão essa que se dá em torno dos conceitos de inerrância e literalidade.
} 
exclusivamente motivados por seus argumentos. Como se assinalou anteriormente, já há uma predisposição popular a algum tipo de mudança, e que se adensa ainda mais a partir da revolta contra um tipo específico de devoção às imagens, característico do final da Idade Média. Dá-se início, então, à separação entre arte e religião (DREHER, 1996, p. 55-56).

Embora o biblicismo não seja, necessariamente, um fruto da Reforma, tem nela o seu ápice na medida em que a Bíblia passa a ser instrumento de toda crítica severa às imagens. Como no centro da Bíblia encontra-se a palavra, pode-se dizer que o século XVI apresenta-se como o predomínio da palavra sobre a imagem e sobre o gesto. Havia, nesse sentido, uma compreensão de que o Verbo eterno triunfaria sobre as hostes da maldade. Entretanto, como bem se expressa Martin Dreher, o século XVI desconhecia certas implicações dessa "tirania da palavra":

Esse conceito de palavra desconhecia estudos histórico-filológicos e também a inflação da palavra através de jornais, revistas, rádio e televisão. Palavra [...] também não era monopólio tirânico de pregadores. Palavra era poder que transportava para os tempos do cristianismo primitivo, no qual não existiam imagens em razão de seu contexto judaico e de sua expectativa do fim iminente (DREHER, 1996, p. 56).

Essa "tirania da palavra" trouxe como principal consequência a destruição da linguagem das imagens, ou seja, destruiu-se o pensamento simbólico constitutivo do cristianismo e também das demais religiões. A destruição da imagem enfraqueceu a dimensão passional da fé (pathos) e reduziu o cristianismo, portanto, ao pensamento conceitual e abstrato. Essa "racionalização" da fé pareceu, a princípio, garantir uma segurança maior na clara compreensão da vontade de Deus para o ser humano. Libertar-se do pathos humano e de todo sentimento que tornasse movediço o terreno sobre o qual se fundaria a revelação, eis aí a grande empreitada da Reforma. Ao evocar a autoridade das Escrituras, portanto, os reformadores acreditavam garantir a integridade da revelação, dentro de um suposto "ambiente higienizado". Mas, a despeito de se operar a partir da "Palavra de Deus", o que dizer da subjetividade a partir da qual a interpretação das 
Escrituras se faz possível? O que dizer das contingências humanas e suas implicações hermenêuticas? Esse tema, com amplas e profundas repercussões epistemológicas, não parece ter sido uma preocupação dos reformadores, embora sua compreensão seja de suma importância para um estudo da revelação.

\section{2 "Solus Spiritus"?}

Como se pode perceber de forma exemplar no iconoclasmo, uma das grandes preocupações da Reforma se concentrou na purificação dos mitos e ritos que se instalaram no cristianismo ao longo de sua história, embora estivesse ausente desse processo a reflexão de que em muitos casos se tratavam de elementos constitutivos da fé cristã. Há, portanto, uma "racionalização" do mito e uma progressiva supressão do rito capaz de produzir especialistas na argumentação de verdades consideradas fundamentais para a fé. Entretanto, na medida em que se manteve alheio às técnicas hermenêuticas desses especialistas, o "leigo" passou a ser vítima de uma velada, mas real, dominação. E a principal técnica hermenêutica em questão, a alegoria, 3 surge como necessidade de se manter a dimensão religiosa do discurso em face à ausência dos mitos. Nesse sentido, a dominação do simbólico, enquanto possível apenas aos detentores do saber religioso, tem o poder de afastar os fiéis do sagrado. 4 No Brasil, por exemplo, há uma diferença significativa entre o catolicismo romano - normalmente marcado pelo domínio difuso dos mitos - e o protestantismo tradicional - este caracterizado por uma sistematização rigorosa dos elementos formadores da crença, postura capaz de produzir uma espécie de "exílio do sagrado". Como consequência desse fenômeno, há uma reverberação de cunho mais popular e laico que aparece como resposta a essa tendência na medida em que procura recuperar o elemento místico da fé cristã. Tal resposta pode ser percebida na maioria dos movimentos místicos que surgem do interior do protestantismo tradicional a partir da década de 1950, e que

\footnotetext{
${ }^{3} \mathrm{~A}$ alegoria, compreendida de forma simples, significaria a arte de pensar e dizer coisas diferentes com as mesmas palavras, ou dizer as mesmas coisas com diferentes palavras.

${ }^{4}$ Cf. MENDONÇA, 2010, p. 483. Esse artigo foi originalmente publicado em 1984, em outra coletânea cujo objetivo foi tematizar sobre o misticismo no Brasil no contexto da religiosidade popular (MENDONÇA, 1984, p.12).
} 
apresentam um início mágico coletivo. Os vários movimentos de cura divina contam-se entre os principais exemplos desse movimento de reação ao tom excessivamente demitologizador do protestantismo tradicional. Inflamados por uma proposta de purificação institucional, tais movimentos dão origem a seguimentos religiosos nos quais a magia-coletiva (cura, exorcismos e etc.) tende a se manifestar como uma espécie de libertação do "sagrado selvagem”. 5 Ou seja, o sagrado outrora exilado em função dessa racionalização imposta, retorna e se reintroduz no discurso ideológico protestante, minando suas defesas, como pode ser visto a partir de alguns dos principais elementos de sua manifestação, tais como a euforia, o êxtase e o misticismo coletivos. Para Antônio Gouvêa Mendonça, esse misticismo se renova constantemente numa reversão de três atos importantes: a magia coletiva, o profetismo e o sacerdotismo. A magia coletiva, na opinião de Mendonça, substitui os poderes meramente éticos e abstratos e precede o ato de louvor e gratidão; o profetismo ${ }^{6}$ se manifesta como crítica às religiões tradicionais; já o sacerdotismo deve ser visto como ato que deriva da progressiva institucionalização (MENDONÇA, 2010, p. 484-485).

Percebe-se, então, um imediatismo na relação com o sagrado capaz de substituir a mediação do discurso - nesse caso, a "invenção" substitui a "reflexão" -, razão pela qual geralmente o misticismo se coloca como uma reação antiintelectualista, quando considerado no contexto da religião. Nessa perspectiva, torna-se desnecessária qualquer intermediação com o sagrado - o que geralmente se faz pelo discurso teológico -, e tal postura resulta na busca por relações imediatas que se consolidem em "experiências espirituais" capazes de colocar o crente em contato “direto" com o sagrado. Essa relação assemelha-se ao que Rudolf Otto denominou de "aspecto irracional do sagrado”, que indica uma relação direta,

\footnotetext{
${ }^{5}$ Nesse sentido, o pentecostalismo pode ser visto como um movimento que se caracteriza por essa "libertação" do sagrado de seu controle institucional, pelo menos parcialmente. Ao tom de contrição, marcado pela culpa, por sacrifícios e penitências - característica predominante das igrejas protestantes -, contrapõe-se o louvor, alegria e entusiasmo das igrejas pentecostais. Naquelas, destaca-se um sagrado irado e vingativo, capaz de manter os fiéis cativos pelo medo, nestas, predomina um sagrado solto, vivo. Ou seja, no protestantismo a liberdade é intelectual, mas não ritual. Por outro lado, tanto as missas católicas quanto os cultos protestantes sustentam um sagrado dominado (Cf. MENDONÇA, 2007).

${ }^{6}$ Alguns consideram a ênfase dada ao profetismo, na perspectiva pentecostal, equivalente à importância dada ao sacerdócio pela primeira geração de protestantes. Nesse caso, a um "sacerdócio de todos os crentes", algo também compartilhado pelos pentecostais, acrescenta-se um "profetismo de todos os crentes" (ver, por exemplo, McGRATH, 2012, p. 421).
} 
sem mediações, estágio originário da religião, que na concepção de alguns precede a própria distinção entre o racional e o irracional. 7 Em sua crítica à tendência racionalista da religião, refletida em seus dias, Otto não nega que esta tenha o seu aspecto racional, instituído. No entanto, pretende destacar aquilo que considera o $a$ priori da religião, a experiência que precede qualquer delimitação e diferenciação possíveis por meio da razão (OTTO, 2005).

Nesse sentido, então, pode-se dizer que o pentecostalismo - enquanto uma das principais manifestações da religiosidade popular no mundo contemporâneo surge como uma retomada do misticismo, razão pela qual elementos tais como o êxtase encontram nele o ambiente adequado para se manifestar e, além disso, se contrapor ao discurso protestante tradicional e sua preferência por uma relação com o sagrado que se circunscreva à mera adesão a um sistema de crenças numa estrutura institucionalizada. No pentecostalismo, o rito é compreendido como prática coletiva, mas, a serviço da produção de “experiências espirituais” em nível individual. Portanto, diferentemente do catolicismo romano - no qual a presença divina se dá através da prática sacramental - e do protestantismo histórico - que celebra a presença divina a partir de seu discurso extremamente racional derivado das Escrituras -, no pentecostalismo Deus se faz presente e se manifesta através dessas "experiências espirituais” possíveis a partir do Espírito. A relação festiva com o sagrado, aqui representado na pessoa do Espírito Santo, suscita o desvelamento da vontade divina, por meio da profecia, de maneira a extrapolar os limites estabelecidos pelas Escrituras, tais como concebidos pelas igrejas protestantes históricas.

Assim, o conceito de revelação na perspectiva pentecostal vincula-se fortemente a qualquer conteúdo que seja dado pelo Espírito ao crente (nível individual) e à igreja (nível coletivo) e que se traduza nas mais variadas experiências místicas, não mediatizadas. Embora explícita e conscientemente um culto pentecostal não prescinda da Palavra, normalmente sua qualidade e

\footnotetext{
${ }^{7}$ Ver, por exemplo, GALIMBERTI, 2003, p. 13.
} 
legitimação não é medida por esta, mas pelo grau com que a presença do Espírito se faz sentir por meio de experiências de transe e êxtase. Ou seja, para um verdadeiro pentecostal, o culto perde todo o seu sentido se não se consegue sentir a presença do Espírito, inclusive no próprio corpo. A centralidade do Espírito na experiência pentecostal pode ser verificada não apenas nas manifestações extáticas, que ocorrem em geral nos cultos e ajuntamentos, mas também em seu imaginário coletivo, o que de certa forma delineia, mesmo que inconsciente e desarticuladamente, certa "teologia da revelação".

$\mathrm{Na}$ experiência pentecostal, há uma forte expectativa de um encontro pessoal com Deus, por meio do Espírito, que em sua imediaticidade supostamente garantiria a pureza da revelação. Ou seja, que revelação poderia ser posta em dúvida, se deriva de um encontro pessoal com o divino, livre da clausura da razão e de sua tendência dessacralizante? Que revelação poderia ser posta em dúvida, se nos é concedida diretamente pelo Espírito Santo? 8 Embora o pentecostalismo exiba diferenças em relação ao protestantismo tradicional, como aqui se tem visto, não se pode ignorar, por outro lado, a semelhança de ambos no que respeita aos respectivos pressupostos. Também no pentecostalismo se desconsidera toda subjetividade que está presente em cada crente e que se interpõe entre este e o sagrado que venera. Ou seja, mesmo se considerarmos a experiência pentecostal como imediata, não se conclui daí que não será posteriormente objeto de interpretação. Além disso, a tradição pentecostal também não consegue escapar do dualismo sagrado-profano. A exagerada ênfase na experiência mística, possível pelo Espírito, também acaba por aumentar o abismo entre Deus e o ser humano no que concerne à revelação. Ou seja, algo tanto mais se legitima como divino - e, portanto, digno de ser crido como sendo a perfeita vontade de Deus - quanto menos sujeito às interferências humanas ele for. É nesse sentido que se pode falar de uma mensagem "de Deus" e uma mensagem "do homem", na medida em que a

\footnotetext{
${ }^{8}$ Algumas expressões recorrentes no "jogo linguístico", presente no interior de muitas comunidades, indicam essa suposta autoridade da revelação, em sua acepção pentecostal: por exemplo, expressões tais como "Deus me falou que...", "senti de Deus que..." ou mesmo "Deus manda lhe dizer que..." surgem como uma espécie de linguagem refratária à contestação na medida em que supostamente flui de Deus diretamente aos fiéis como palavra indefectível.
} 
primeira é fruto de uma revelação que procede diretamente de Deus e a segunda é aquela que supostamente se encontra comprometida por exibir as marcas e limitações de uma humanidade pecaminosa. Esse dualismo, portanto, impede que se veja o mundo e o humano como "lugares" possíveis da revelação.

\section{A revelação na dimensão do humano}

Como se pôde ver até aqui, partimos do pressuposto de que tanto no protestantismo histórico quanto no pentecostalismo - conquanto exibam características distintas e ao mesmo tempo complementares - o conceito de revelação desconsiderou um elemento significativamente importante: a dimensão humana e suas contingências. Nos dois casos, recorre-se a uma suposta "garantia" da pureza da revelação. No caso do protestantismo histórico, tal garantia fora buscada nas Escrituras; no caso do pentecostalismo, essa segurança fora afiançada por meio do Espírito. Entretanto, não se constituiu uma preocupação histórica dessas duas vertentes do protestantismo a recepção da revelação. Ou seja, a necessidade de se fugir das limitações humanas no processo de revelação, fez com que esta fosse concebida sempre a partir de cima, nunca a partir de baixo. Há, portanto, "vazios" nesse processo que inevitavelmente forçam o crente a interferir criativamente e a dialogar com os conteúdos concedidos tanto pelas Escrituras quanto por uma relação epifânica e direta com o sagrado, mas que de alguma forma não foram levados em conta por essas duas tradições. Em função de tal lacuna, propõe-se aqui uma revelação que não prescinda dos elementos humanos, mas que assuma a recepção como critério hermenêutico-teológico. A recepção, portanto, pressupõe os filtros constituídos pelos elementos de nossa "mundanidade" e que, por outro lado, constituem os limites de compreensão dessa revelação. Vejamos, então, de que tipo de revelação estamos falando.

Em primeiro lugar, propõe-se uma revelação que se dê nos limites da história. Em função de um dualismo sempre recorrente na história do cristianismo, percebe-se uma tendência, ainda presente, em se compreender a 
revelação como conteúdo que "cai do alto", alheado da radical intimidade do ser humano, rompendo com a imanência e ameaçando o princípio da autonomia. Entretanto, sustenta-se aqui que não podemos pressupor uma relação com Deus abstraída da trama histórica de nossa própria existência, uma vez que o acessamos apenas pela mediação da vivência humana. Ou seja, à semelhança do que propõe Martin Heidegger, o ser humano é ser-no-mundo, o que significa que se experimenta sempre como um sujeito situado, cujas experiências (mesmo as transcendentais) se dão em sua própria finitude. O “mundo", assim, designa a esfera das relações que o ser humano possui com a realidade. Nesse sentido, o ser humano também se efetiva a partir de sua presença mundana, presença que se dá diante dos objetos e eventos cuja relação constitui o “mundo" (VAZ, 1992, p. 15).

A história humana, então, é pressuposto para a revelação divina. Confirmanos isso o teólogo belga Edward Schillebeeckx, em sua tentativa de superação da tese exclusivista "extra ecclesiam nulla salus" ("fora da Igreja não há salvação"), declarada no Concílio de Ferrara-Florença, em 1442. Numa contrapartida a tal declaração, e em sintonia com o conceito heideggeriano de ser-no-mundo, Schillebeeckx propõe sua radical formulação "extra mundum nulla salus" ("fora do mundo não há salvação”), a partir da qual a revelação passa a ter estrutura sacramental na medida em que o evento profano se constitui matéria-prima para a “palavra de Deus" (SCHILLEBEECKX, 1994). Ou seja, todo sentido religioso que se extrai de um processo mundano pressupõe um sentido humano. Para Schillebeeckx, as realizações humanas significativas constituem base para a revelação, afinal, qualquer acontecimento que seja libertador já é humanamente relevante, ainda que não faça referência direta a Deus - "etsi deus non daretur" ("mesmo se Deus não existisse”). Por outro lado, na opinião do teólogo belga, em histórias de sofrimento e opressão, Deus só se revela como veto ou julgamento. Como o sentido religioso é sempre posterior e dependente do sentido humano, isso significa que no nível da libertação humana, tanto crentes quanto incrédulos podem se expressar, em linguagem comum, num diálogo que se manifesta tanto em acordos quanto em cooperação. Assim, falar de Deus, sem o devido lastro 
humano e histórico, pode suscitar um discurso que se construa a partir de uma imagem envelhecida de Deus (SCHILLEBEECKX, 1994, p. 24). Como em Jesus, os eventos humanos libertadores constituem os meios através dos quais os crentes podem reconhecer o rosto de Deus. Nesse caso, o sentido religioso torna-se incredível sem o sentido humano. Além disso, a salvação-vinda-de-Deus realiza-se primariamente na realidade mundana da história, e só posteriormente na consciência dos crentes, como revelação (SCHILLEBEECKX, 1994, p. 25-26, 2930).

Em segundo lugar, propõe-se uma revelação que se dê nos limites da linguagem. Tal proposta contrasta-se com duas pretensões: a de se propor uma revelação que se dê em bases metafísicas, ou seja, que insista em falar em Deus como aquele que é; e a de se esgotar a revelação na palavra, no dizer. Ambas incorrem num mesmo erro: pressupor que a linguagem, a partir da qual significamos o mundo, expressa a realidade como ela é. Ou seja, pressupõe-se equivocadamente que a revelação constitui-se em manifestação direta e inevitável do objeto revelado, o objeto em-si-mesmo.

Com relação à primeira pretensão, pode-se dizer que pressupor uma revelação que supere sua matriz metafísica significaria compreendê-la a partir de uma perspectiva humana, a partir da maneira como somos tocados pela realidade de Deus, enfim, a partir da recepção. Viver a realidade do divino deriva, então, de uma experiência conscientemente pessoal e situada. Não haveria, portanto, a pretensão de se arvorar para além desse para-nós, em direção a uma concepção metafísica e universalizante. A perspectiva de Joseph Moingt, segundo a qual Deus deve ser compreendido como um ser-para-nós, é relevante aqui (MOINGT, 2010). Nessa perspectiva, a revelação divina em Jesus torna-se parâmetro na medida em que Deus deixa de ser compreendido tanto como o Deus absoluto, infinito e necessário da filosofia, quanto como o Deus Onipotente da religião. Ou seja, em Jesus, morre o Deus da metafísica, o Totalmente Outro das antigas religiões, alheado do drama humano tanto quanto deficiente de presença mundana. Trata-se, 
portanto, de uma revelação que possibilita que Deus seja recebido em um acontecimento singular, compreendido por meio da linguagem humana e por ela feito mensagem.

A percepção de Moingt nos convida, então, a compreendermos Deus, não mais como aquele que é, concebido na perspectiva da necessidade, mas como aquele que vem, que pode ser alcançado na perspectiva da gratuidade. Uma revelação que seja compreendida em toda a sua complexidade passa por compreender o Deus que é-para-nós como aquele que é tal como aparece. Nesse sentido, a proposta de um Deus-para-nós amplia nosso horizonte ontológico na medida em que podemos integrar ao ser de Deus sua relação com o mundo, o que delineia também sua história conosco. Ou seja, conceber um Deus que se faz paranós implica em compreendê-lo sempre a partir de suas relações com o mundo nesse caso, a identidade divina não se define em si mesma, portanto, Deus também passa a ser na relação. Como nos lembra Moingh, a compreensão de Deus deve se estender à fé em Deus, afinal, o objeto da fé não pode ser separado da subjetividade da fé que se funda nele a partir do discurso que o enuncia, não importa o quanto isso soe escandaloso à teologia clássica (MOINGT, 2010, p. 15). Nas palavras de Moingt, um dos grandes desafios da teologia consiste em reconciliar o para-nós com o em-si de Deus:

Os teólogos [...] interessaram-se pelos mistérios da eternidade mais que pelas realidades da história, e foi desta maneira que a ideia de Deus terminou por se obscurecer nas especulações da metafísica. A tarefa da teologia hoje - e numerosos teólogos se engajaram nessa via - é reconciliar o em-si de Deus e seu para-nós, sua eternidade e sua presença no tempo. É a condição para reconciliar o pensamento da modernidade com a revelação cristã compreendida sob esta nova luz. É também a condição para fundar sobre Deus mesmo a autonomia e a consistência do mundo (MOINGT, 2010, p. 437).

Com relação à segunda pretensão, pode-se buscar na tradição hermenêutica que se constrói desde Nietzsche até os movimentos que se seguiram à chamada 
Linguistic Turn, ${ }^{9}$ nas primeiras décadas do século $\mathrm{XX}$, o suporte para se pensar a revelação nos limites da linguagem. A partir desse horizonte teórico pode-se dizer que a linguagem não é mais vista como representação fiel da realidade-em-si, o que significa que a estrutura ontológica não corresponde mais à estrutura linguística. Ou seja, o que o mundo é não se revela plena e claramente no código linguístico. Se por um lado, o ser humano é alguém que continuamente indaga pelo sentido das coisas - e, consequentemente, sente a necessidade do dizer - , por outro, ele só tem acesso àquilo que se encontra nos limites da linguagem, sendo esse também os limites de sua teologia. A produção de conhecimentos que garantam algum sentido - como, por exemplo, a formulação de teologias - é sempre uma necessidade humana, mas não se pode ignorar o fato de que deve sempre fazer jus à finitude do ser humano. Isso significa abrir mão da ânsia, sempre à espreita, de se construir conceitos que sejam acabados. Então, se em certo sentido é impossível não se fazer teologia a partir de nossas impressões da realidade de Deus que reverbera no mundo dos humanos, urge a necessidade de construirmos uma "teologia de textos escritos” que se arrisque na ação do dizer, mas, que não se arvore para além dos limites da linguagem, o que pressupõe certa humildade nessas formulações.

Quando nos referimos a uma revelação que seja compreendida nos limites da linguagem, inevitavelmente pressupomos uma base epistemológica frágil, kenótica. Isso equivale a afirmar que o mundo-em-si não é o mundo dos fenômenos, o mundo de sentido, o mundo em relação ao qual temos acesso. ${ }^{10}$ Para além do niilismo de Nietzsche, partimos do pressuposto de que é possível se falar da coisa-em-si na medida em que se admite que a realidade extrapola a linguagem, ou seja, ao se pressupor que a linguagem é limitada para abarcar todas as coisas,

\footnotetext{
${ }^{9}$ A Linguistic Turn ("Virada Linguística") diz respeito a um movimento que consolida o paradigma segundo o qual a linguagem não será mais compreendida como objeto da reflexão filosófica, mas a própria reflexão filosófica de todo pensar. A linguagem, nesse novo paradigma, passará a ser uma realidade capaz de exprimir tudo o que se possa dizer sobre o "mundo", o que significa que não haverá mais mundo independente da linguagem. Toda inteligibilidade e expressividade do mundo encontram-se, agora, reféns de seus limites - a linguagem, portanto, torna-se constitutiva de qualquer saber humano.

${ }^{10}$ Nietzsche, seguindo os passos de Schopenhauer, concebia o mundo em-si-mesmo - ou seja, o mundo fora de nossas interpretações, de nossa subjetividade - como independente do sujeito que o conhece e, portanto, como algo distinto do fenômeno - ou seja, o mundo já mediatizado pelos "filtros" de nossa subjetividade. Para Nietzsche, portanto, toda ordenação epistemológica e moral do mundo estão presentes apenas no fenômeno, afinal, em suas palavras, "tudo somente - humano, demasiado humano". Esta frase nomeia uma das obras de Nietzsche e se encontra presente no prólogo desse livro, §1, onde supostamente, nas palavras do filósofo, descreveria o suspiro de seus leitores em face da leitura de seus livros (Cf. NIETZSCHE, 2005).
} 
incluindo nossas experiências. Então, a questão não é se existem absolutos ou não, mas se temos acesso ao absoluto absolutamente. A resposta negativa a essa questão inaugura, necessariamente, um discurso que pressupõe a fragilidade. Portanto, a consciência da necessidade humana do dizer, somada à impossibilidade de se compreender Deus plenamente e traduzi-lo num discurso, exige que se construa uma teologia da revelação que se funde nessa vulnerabilidade humana. Tal constatação, nesse sentido, endereça-nos ao nosso último pressuposto.

Em terceiro lugar, propõe-se uma revelação que se dê nos limites da vulnerabilidade humana. Como temos visto, a realidade-em-si não se esgota na linguagem, não possui nela o seu termo - ela sempre sobra para além de suas próprias descrições. Nesse sentido, a teologia deve evitar o perigo dos ídolos conceituais e compreender-se como atividade que procede por sucessivas aproximações, interpretações que se mostram cada vez mais adequadas, cujo devir de suas manifestações já aponta para uma reserva que demonstra o caráter elusivo da revelação (GEFRÉ, 2004, p. 39). Ou seja, se por um lado o limite de nossa teologia é o limite de nossa linguagem, por outro, a realidade extrapola a linguagem. Mas, o problema é que a tradição metafísica acostumou-se a fazer declarações "fortes" a respeito disso que extrapola nosso mundo linguístico. Urge a necessidade, então, de assumirmos outra postura com relação a essa revelação que nunca se esgota no revelado, afinal, no horizonte do dizer sempre se encontra também o não dito.

A dimensão linguística da revelação pressupõe uma experiência humana, o que nos impõe a necessidade, não apenas de uma "teologia de textos escritos", mas, também, de uma “teologia da pessoa”. A revelação, no sentido aqui pretendido, é indissociavelmente linguagem e experiência. O cristianismo bíblico é um exemplo disso, na medida em que não se manifesta primariamente como uma mensagem na qual se deva crer, mas trata-se de uma experiência de fé que se transforma numa mensagem. Ou seja, há uma experiência de fé cujo relato inicial dá testemunho do 
seu caráter inefável e que, posteriormente, se traduz numa diversidade de linguagens que constituem o Novo Testamento. Nesse sentido, afora a singularidade do evento pascal, há um "chão" comum que reúne essa experiência a qualquer outro "experimento" do sagrado.

Embora a formulação linguística da experiência humana seja uma etapa no processo, existem questões que parecem extrapolar a linguagem, como experiências de dor e sofrimento ou mesmo experiências religiosas, cuja descrição é absolutamente impossível de ser feita a contento. A linguagem sempre deixará escapar alguma coisa presente na experiência originária, não importa o quão precisa ela seja. Nesse caso, a própria consciência de que a linguagem é limitada para descrever a realidade, nos levaria à necessidade de concomitantemente trabalhar na construção de uma teologia de "textos vivos”. Essa teologia deveria valorizar as experiências humanas, consciente de que nem sempre estarão respaldadas nos parâmetros normativos que se estabelecem a partir das descrições teológicas vigentes. Ou seja, para além dos textos “normativos” e da verdade que daí derivou, existem pessoas de "carne e osso", que como tais devem ser consideradas nas formulações teológicas, além de se tornarem pressupostos para as mesmas. ${ }^{11}$ Considerar as pessoas e suas vulnerabilidades como parâmetro teológico também indica o tipo de relação que se deve ter para com essa teologia.

Se há bons instrumentos para a compreensão de uma teologia da revelação em seu aspecto linguístico-discursivo, deveríamos agora buscar instrumentos que nos ajudem na construção de uma teologia da revelação em seu aspecto humanoexperiencial. E, nesse sentido, a tradição latino-americana constitui-se numa importante materialização histórica dessa vulnerabilidade assumida como critério hermenêutico-teológico. Se quisermos compreender a revelação a partir de uma teologia de "textos vivos", devemos encontrar nossa melhor tradição na América Latina (AL), na medida em que seu projeto epistemológico é muito mais afeito ao

\footnotetext{
11 Vale ressaltar que assim como a consciência de limitação da linguagem nos força a uma "teologia da pessoa" - a linguagem apontando para o humano como sua condição —, o caráter inabarcável da experiência humana também exige uma teologia "aberta" — o humano como exigência do tipo de linguagem que se deve usar.
} 
humano e suas contingências. A força propulsora dessa hermenêutica é a legitimação do fraco e oprimido, mas, para além disso, também a construção de um projeto epistemológico que se funde na descolonização e assunção da vulnerabilidade.

Várias características traduzem essa fragilidade a partir da qual a hermenêutica latino-americana se propõe. Tal fragilidade se evidencia nos "palcos" a partir dos quais se faz ouvir. Nesse sentido, não se fará mais presente na pura "identidade" e nos lugares "familiares" do texto bíblico, nas interpretações já consagradas, mas numa alteridade e estranhamento que passaram a ser acolhidos como critério hermenêutico. Não se restringirá à cristalização e sacralização das Escrituras em seu ambiente de origem, mas se encontrará na mistura do texto com a realidade e demanda do ouvinte, sobretudo em sua história de opressão. A fragilidade que motiva essa nova epistemologia, portanto, também se insurge contra a colonização do texto bíblico, ao privilegiar os coadjuvantes e seu testemunho, as narrativas de luta e opressão e as utopias sepultadas sob camadas de séculos de tradição interpretativa.

A vulnerabilidade é um elemento constitutivo de nossa humanidade - "ser humano é ser vulnerável" -, já nos lembrou o teólogo norueguês Sturla Stalsett. ${ }^{12}$ Negá-la, portanto, é desumanizante e tal postura se encontra presente em muitas formulações que se fundam na "força", tais quais as propostas pelos variados tipos de fundamentalismo. A vulnerabilidade, nesse sentido, torna-se o pressuposto de toda sensibilidade, compaixão e comunidade, elementos caros à tradição hermenêutica latino-americana e - por que não dizer? - necessários a qualquer teologia da revelação que faça jus a essa vulnerabilidade humana.

${ }^{12}$ Cf. STALSETT, 2004, p. 145-157. Ver, também, STALSETT, 2002, p. 33. 


\section{Conclusão}

Os recursos de que dispomos atualmente para compreensão da revelação inviabilizam a construção de conceitos que se sustentem a partir de um sola-solus. Ou seja, não se propõe aqui um conceito de revelação que seja meramente abstraído das Escrituras ou mesmo de uma relação mais direta e imediata com o divino. Nosso objetivo é propor que sua compreensão inclua, também, a dimensão humana como constitutiva. Portanto, em lugar de um "somente", seria mais razoável um "também”. Nesse sentido, tanto a interpretação das Escrituras quanto a experiência com o divino mediada pelo Espírito não podem prescindir dos "filtros" que constituem nossa subjetividade, o que significa que esse “desvelamento" não pode driblar nossa "mundanidade", ao contrário, ele a pressupõe. Assim, esses elementos - as Escrituras e a experiência com o Espírito - estão indissociavelmente ligados ao e inevitavelmente afetados pelo humano e suas contingências.

A compreensão da revelação, tal como aqui proposta, pressupõe, então, que se leve em conta a história humana e suas vicissitudes na compreensão da revelação. Significa reviver as Escrituras a partir dos vários "lugares hermenêuticos", sobretudo aqueles nos quais predomina a opressão, onde as experiências (mesmo as transcendentais) incluam também as dúvidas, a procura, a necessidade, o fracasso e até mesmo a negação.

\section{REFERÊNCIAS}

DELUMEAU, J. Nascimento e afirmação da reforma. São Paulo: Pioneira, 1989.

DREHER, M. N. A crise e a renovação da igreja no período da Reforma. São Leopoldo: Sinodal, 1996.

ELIADE, M. Mito do eterno retorno. São Paulo: Mercuryo, 1992.

GALIMBERTI, U. Rastros do sagrado: o cristianismo e a dessacralização do sagrado. São Paulo: Paulus, 2003. 
GEFRÉ, C. Crer e interpretar: a virada hermenêutica da teologia. Petrópolis, RJ: Editora Vozes, 2004.

McGRATH, A. A revolução protestante: uma provocante história do protestantismo contada desde o século 16 até os dias de hoje. Brasília, DF: Palavra, 2012.

MENDONÇA, A. G. A volta do sagrado selvagem: misticismo e êxtase no protestantismo do Brasil. In: AUGUSTO, A. M. (Org.). Ainda o sagrado selvagem: homenagem a Antônio Gouvêa Mendonça. São Paulo: Fonte Editorial; Paulinas Editora, 2010.

MENDONÇA, A. G. A volta do sagrado selvagem: misticismo e êxtase no protestantismo do Brasil. In: MENDONÇA, A. G. et al. Religiosidade popular e misticismo no Brasil. São Paulo: Editora Paulinas, 1984.

MENDONÇA, A. G. De novo o sagrado selvagem: variações. Estudos de religião, São Bernardo do Campo, v. 21, n. 32, p. 22-33, jan/jun 2007.

MOINGT, J. Deus que vem ao homem: do luto à revelação de Deus - vol. 1. São Paulo: Edições Loyola, 2010.

NIETZSCHE, F. Humano, demasiado humano: um livro para espíritos livres. São Paulo: Companhia das Letras, 2005.

OTTO, R. Lo santo: lo racional e lo irracional em la idea de Dios. Madrid: Alianza Editorial, 2005.

RUBIO, A. G. Novos rumos da antropologia teológica cristã. In: RUBIO, A. G. (Org.). O humano integrado: abordagens de antropologia teológica. 2. ed. Petrópolis: Vozes, 2007.

SCHILLEBEECKX, E. História humana: revelação de Deus. São Paulo: Paulus, 1994.

STALSETT, S. J. El sujeto, los fundamentalismos y la vulnerabilidad. Pasos, San José, n. 104, Segunda Época: DEI, 2002.

STALSETT, S. J. Vulnerabilidad, dignidade e justicia: valores éticos fundamentales em um mundo globalizado. Revista Venezolana de Gerencia, Maracaibo, v. 9, n. 25, 2004, p. 145-157.

VAZ, H.C.L. Antropologia filosófica II. São Paulo: Loyola, 1992.

WACHHOLZ, W. História e teologia da Reforma: introdução. São Leopoldo: Sinodal, 2010. 